\title{
STUDIES ON THE CLOT-PROMOTING ACTIVITY OF GLASS
}

\author{
BY ELEAZAR SHAFRIR AND ANDRE DE. VRIES 1
}

\author{
(From the Department of Clinical Research, Hebrew University-Hadassah Medical School, \\ Jerusalem, Israel)
}

(Submitted for publication February 21, 1956; accepted March 28, 1956)

Although the clot-promoting activity of foreign surfaces has been the subject of many studies during almost a century (1) its nature is not yet understood. While glass has been thought to activate platelets (2), recent studies have mostly been concerned with the effect of glass on plasma clotting factors.

Quick maintained that contact with glass activates the precursor of prothrombin, prothrombinogen (3) as well as the precursor of plasma thromboplastin, possibly antihemophilic factor A (4). Conley and his associates (5-8) have reported that contact with glass markedly shortens the clotting time of silicone prepared "platelet free" plasma and increases its prothrombin utilization. They concluded that glass activates "plasma thromboplastin," a constituent residing in the globulin fraction. Biggs, Douglas, and Macfarlane (9) stated that the increased clotting activity developed in plasma by contact with glass is probably due to a change in Christmas Factor (PTC, antihemophilic factor B). Alexander, de Vries, and Goldstein (10) observed that contact with glass during clotting of blood favors the evolution of SPCA (convertin, Factor VII). Rapaport, Aas, and Owren (11) showed that exposure to glass markedly increases the activity of proconvertin as well as of PTC. Other communications $(12,13)$ attributed the clot-promoting activity of glass to removal of lipid or protein inhibitors of the first phase of coagulation, i.e., the evolution of thromboplastic activity.

In the present study it is shown that a plasma clotting factor other than those mentioned above may be activated by contact with glass.

\section{MATERIALS AND METHODS}

Collection of blood. Human venous blood was collected by the two-syringe method using silicone 2 coated needles and glassware.

\footnotetext{
1 Present Address : Department of Medicine, Beilinson Hospital, Petah-Tikva, Israel.

2 A 3 per cent solution in $\mathrm{CCl}_{4}$ of DC 200 Silicone Fluid, Dow Corning Co., Midland, Mich., U. S. A.
}

Native "platelet free" (PF) plasma. Blood collected into a syringe chilled by an ice jacket was centrifuged at $4^{\circ} \mathrm{C}$ for 10 minutes at $14,000 \mathrm{~g}$ in a Servall angle centrifuge. The supernatant plasma was separated and used immediately.

Oxalated "platelet free" ( $P F)$ plasma. One part of blood was mixed in a centrifuge tube with 19 parts of $0.2 \mathrm{M}$ sodium oxalate. After chilling on ice for $5 \mathrm{~min}$ utes the blood was centrifuged at $4^{\circ} \mathrm{C}$ for 15 minutes at $14,000 \mathrm{~g}$. The supernatant plasma was separated and used within an hour. Platelet counts performed on the undiluted supernatant by the method of Conley, Hartmann, and Morse (5) showed that the number of platelets rarely exceeded 20 per mm." (mean \pm S.D. of 40 plasmas was $14 \pm 12$, range 0 to 56 per $\mathrm{mm}^{2}$ )

"Platelet free" (PF) BaSO,-plasma (prothrombin-, proconvertin-, and PTC-free plasma). Finely powdered BaSO. (Merck) was suspended in oxalated PF plasma, $50 \mathrm{mgm}$. per $\mathrm{ml}$. The suspension was kept at $20^{\circ} \mathrm{C}$ for 20 minutes and stirred from time to time; subsequently the $\mathrm{BaSO}_{4}$ was sedimented by centrifugation for $10 \mathrm{~min}$ utes at $10,000 \mathrm{~g}$ and $4^{\circ} \mathrm{C}$.

Isolation of platelets. One part of blood was mixed with 9 parts of a solution of 1 per cent EDTA ${ }^{3}$ and 1 per cent Triton 4 in 0.7 per cent $\mathrm{NaCl}$ and chilled on ice. All subsequent procedures were carried out at $4^{\circ} \mathrm{C}$. Platelet rich plasma was obtained by centrifugation of the blood at $500 \mathrm{~g}$ for 10 minutes and platelets were sedimented from this plasma by a second centrifugation for 5 minutes at $8,000 \mathrm{~g}$. The sedimented platelets were rinsed and carefully resuspended in a washing fluid containing 0.05 per cent EDTA, 0.05 per cent Triton and $0.02 \mathrm{M}$ sodium acetate in 0.7 per cent $\mathrm{NaCl}$. The suspension was again centrifuged at $8,000 \mathrm{~g}$ for 5 minutes and the washing procedure repeated. The platelets were finally resuspended in 0.9 per cent $\mathrm{NaCl}$ and counted by the method of Rees and Ecker (14). Phase microscopic examination showed the platelets to be morphologically intact.

Activation with glass powder. Pieces of clean Pyrex glass were crushed in a mortar to fine powder. The specific surface area of the powder was $2,500 \mathrm{~cm}$. per $\mathrm{gm}$. as determined with the methylene blue absorption method (15). Various plasmas were added to glass powder in a siliconed test tube as described in the results. The mixtures were kept at room temperature $\left(20\right.$ to $\left.22^{\circ} \mathrm{C}\right)$,

8 Ethylene Diamine Tetra-Acetic Acid disodium salt (Sequestrene), Alrose Chemical Co., Providence, N. J., U. S. A.

- Triton W. R. 1339, Rohm and Haas Co., Philadelphia, Pa., U. S. A. 
TABLE I

The effect of contact of oxalated PF plasma with varying quantities of glass powder on the clotting time and serum prothrombin and convertin content *

\begin{tabular}{|c|c|c|c|c|c|c|c|c|}
\hline \multirow{2}{*}{$\begin{array}{c}\text { Glass powder } \\
\text { in contact } \\
\text { with } 0.4 \mathrm{ml} . \\
\text { plasma } \\
(\mathrm{mgm.})\end{array}$} & \multicolumn{2}{|c|}{$\begin{array}{c}\text { Clotting time } \\
(\min .)\end{array}$} & \multicolumn{2}{|c|}{$\begin{array}{c}\text { Serum prothrombin } \dagger \\
(\%)\end{array}$} & \multicolumn{2}{|c|}{$\begin{array}{l}\text { Serum prothrombin } \neq \\
(\%)\end{array}$} & \multicolumn{2}{|c|}{$\begin{array}{c}\text { Serum convertin } \\
(\%)\end{array}$} \\
\hline & $\begin{array}{c}\text { Glass } \\
\text { removed }\end{array}$ & $\begin{array}{c}\text { Glass } \\
\text { present }\end{array}$ & $\begin{array}{c}\text { Glass } \\
\text { removed }\end{array}$ & $\begin{array}{c}\text { Glass } \\
\text { present }\end{array}$ & $\begin{array}{c}\text { Glass } \\
\text { removed }\end{array}$ & $\begin{array}{c}\text { Glass } \\
\text { present }\end{array}$ & $\begin{array}{c}\text { Glass } \\
\text { removed }\end{array}$ & $\begin{array}{c}\text { Glass } \\
\text { present }\end{array}$ \\
\hline $\begin{array}{r}0 \\
2 \\
10 \\
50 \\
150 \\
300\end{array}$ & $\begin{array}{l}8 \\
8 \\
7 \\
6 \\
7\end{array}$ & $\begin{array}{l}7 \\
6 \\
4 \\
3 \\
2\end{array}$ & $\begin{array}{l}80 \\
75 \\
53 \\
45 \\
40\end{array}$ & $\begin{array}{ll}3 & \\
70 \\
62 \\
42 \\
35 \\
20\end{array}$ & $\begin{array}{l}62 \\
64 \\
43 \\
40 \\
35\end{array}$ & $\begin{array}{l}40 \\
38 \\
30 \\
22 \\
16\end{array}$ & $\begin{array}{r}100 \\
120 \\
88 \\
63 \\
60\end{array}$ & $\begin{array}{r}123 \\
110 \\
57 \\
33 \\
10\end{array}$ \\
\hline
\end{tabular}

* Four-tenths ml. oxalated PF plasma treated with glass powder was recalcified with $0.1 \mathrm{ml}$. of $0.05 \mathrm{M} \mathrm{CaCl}_{2}$, either after removal of the glass or in its presence.

$t$ Method of Rosenfield and Tuft (16).

$\mp$ Method of Owren and Aas (17).

shaken gently by hand from time to time and after 10 minutes of contact centrifuged for 10 minutes at $3,000 \mathrm{~g}$. In the different experiments either the supernatant glass activated plasma was transferred to another siliconed tube, or the glass was left suspended in the plasma in the original tube.

Clotting times were measured at $37^{\circ} \mathrm{C}$ in siliconed test tubes, internal diameter $11 \mathrm{~mm}$.

Determination of clotting factors. Plasma and serum prothrombin were determined by the one stage procedure of Rosenfield and Tuft (16) and by the method of Owren and Aas (17). SPCA (convertin, Factor VII) in serum was assayed by the method of de Vries, Alexander, and Goldstein (18). Determination of proaccelerin (plasma Ac-globulin, labile factor) was performed by the method of Stefanini (19).

\section{RESULTS}

1. Some factors influencing the clot-promoting activity of glass on PF plasma

Quantity of glass; presence of glass during clotting. The effect of varying quantities of glass powder on the clotting time of oxalated PF plasma is shown in Table I. There was a marked difference in the clot-promoting effect of glass according to whether the glass was removed from the plasma before recalcification or whether the plasma was recalcified in the presence of glass. In both cases a small quantity of glass powder accelerated clotting. Larger quantities of glass powder, if present during clotting caused additional clot-acceleration but if removed before recalcification, had no such effect. In addition, with increasing amounts of glass, serum prothrombin values decreased. While with both procedures serum convertin increased markedly, additional quantities of glass powder caused a decrease in this factor. The decrease in serum prothrombin and convertin was more pronounced when glass remained during clotting.

Duration of contact with glass. In experiments in which the glass powder was removed from plasma before recalcification it was found that the clot-acceleration by a 2-minute contact was not increased by prolongation of the contact to 120 minutes.

Temperature during glass contact. Oxalated PF plasma was brought into contact with glass powder at $2^{\circ}, 20^{\circ}, 37^{\circ}$ and $42^{\circ} \mathrm{C}$. After $10 \mathrm{~min}$ -

TABLE II

Clot promoting activity induced by glass in PF plasma: Effect of decalcifying agents

\begin{tabular}{lcc}
\hline & \multicolumn{1}{c}{$\begin{array}{c}\text { Clotting time* of DP plasma } \\
\text { (minutes) }\end{array}$} \\
\cline { 2 - 3 } Decalcifying agent & $\begin{array}{c}\text { Without } \\
\text { glass }\end{array}$ & $\begin{array}{c}\text { Glass } \\
\text { treated }\end{array}$ \\
\hline Sodium oxalate, 0.2 M† & 16 & 8 \\
Sodium fluoride, 0.4 M† & 18 & 10 \\
Sodium citrate, 0.2 M† & 16 & 9 \\
EDTA, 1\% & 15 & 7 \\
Amberlite IRC 508 & 10 & 8 \\
Dowex 508 & 11 & 9
\end{tabular}

* The amounts of $\mathrm{CaCl}_{2}$ applied were optimal for the differently decalcified PF plasmas.

$\uparrow$ Mixed with blood in the proportion of 1 to 19 . Fourtenths $\mathrm{ml}$. of the derived PF plasma was recalcified with $0.1 \mathrm{ml}$. $\mathrm{CaCl}_{2} 0.05 \mathrm{M}$.

$\mp$ Ethylene diamine tetra-acetic acid disodium salt was added to the blood in the proportion of 1 to 9 . Fourtenths $\mathrm{ml}$. of the derived PF plasma was recalcified with $0.1 \mathrm{ml}$. $\mathrm{CaCl}_{2} 0.03 \mathrm{M}$.

8 Whole blood was shaken for 10 minutes with $1 / 4$ volume of the ion exchange resin (on the sodium cycle at $\mathrm{pH} 7.7$ ) in a siliconed Erlenmayer flask. Four-tenths $\mathrm{ml}$. of the derived $\mathrm{PF}$ plasma was recalcified with $0.1 \mathrm{ml}$. of $\mathrm{CaCl}_{2}$ $0.02 \mathrm{M}$. 
TABLE III

Clotting time and residual serum prothrombin * of oxalated $P F$ plasma recalcified in the presence of glass-treated platelets

\begin{tabular}{|c|c|c|c|c|c|c|c|c|}
\hline \multirow[b]{4}{*}{$\begin{array}{c}\text { Number of } \\
\text { platelets per } \\
\text { mm.: of final } \\
\text { clotting } \\
\text { mixture† }\end{array}$} & \multicolumn{8}{|c|}{ Platelets } \\
\hline & \multicolumn{4}{|c|}{ Whole } & \multicolumn{4}{|c|}{ Frozen and thawed } \\
\hline & \multicolumn{2}{|c|}{ Without glass } & \multicolumn{2}{|c|}{ Glass treated } & \multicolumn{2}{|c|}{ Without glass } & \multicolumn{2}{|c|}{ With glass } \\
\hline & $\begin{array}{c}\text { Clotting } \\
\text { time } \\
\text { (min.) }\end{array}$ & $\begin{array}{c}\text { Serum } \\
\text { pro- } \\
\text { thrombin } \\
(\%)\end{array}$ & $\begin{array}{c}\text { Clotting } \\
\text { time } \\
\text { (mix.) }\end{array}$ & $\begin{array}{c}\text { Serum } \\
\text { pro- } \\
\text { thrombin } \\
(\%)\end{array}$ & $\begin{array}{c}\text { Clotting } \\
\text { time } \\
\text { (mix.) }\end{array}$ & $\begin{array}{c}\text { Serum } \\
\text { pro- } \\
\text { thrombin } \\
(\%)\end{array}$ & $\begin{array}{c}\text { Clotting } \\
\text { time } \\
\text { (min.) }\end{array}$ & $\begin{array}{c}\text { Serum } \\
\text { pro- } \\
\text { thrombin } \\
(\%)\end{array}$ \\
\hline $\begin{array}{r}160,000 \\
16,000 \\
1,600 \\
400 \\
100 \\
25 \\
0\end{array}$ & $\begin{array}{r}5 \\
7 \\
9 \\
13 \\
14 \\
14 \\
14\end{array}$ & $\begin{array}{r}3 \\
19 \\
68 \\
184 \\
196 \\
210 \\
200\end{array}$ & $\begin{array}{l}4.5 \\
7.5 \\
10 \\
14 \\
15 \\
14 \\
15\end{array}$ & $\begin{array}{r}3 \\
18 \\
80 \\
200 \\
200 \\
220 \\
206\end{array}$ & $\begin{array}{r}6 \\
8 \\
11 \\
15 \\
16 \\
15 \\
16\end{array}$ & $\begin{array}{r}3 \\
16 \\
60 \\
180 \\
186 \\
182 \\
190\end{array}$ & $\begin{array}{r}7 \\
9 \\
10 \\
13 \\
16 \\
16 \\
15\end{array}$ & $\begin{array}{r}3 \\
20 \\
75 \\
160 \\
200 \\
180 \\
194\end{array}$ \\
\hline
\end{tabular}

* Determined by the method of Rosenfield and Tuft (16). Values in excess of 100 per cent obtained with this method are discussed by de Vries, Herz, and Heiman-Hollander (20).

† One-tenth ml. of $\mathrm{CaCl}_{2} 0.05 \mathrm{M}$ added to a mixture of $0.3 \mathrm{ml}$. oxalated PF plasma and $0.1 \mathrm{ml}$. of counted platelet suspension.

$\ddagger$ One $\mathrm{ml}$. of suspensions containing varying number of platelets were put in siliconed tubes (internal diameter 20 mm.) containing $200 \mathrm{mgm}$. of glass beads $0.1 \mathrm{~mm}$. in diameter and rotated on a disc at a slant of $45^{\circ}$ at $20 \mathrm{rpm}$. After 15 minutes of rotation the glass beads were allowed to settle for 10 minutes and the supernatant platelet suspensions separated and used in the experiment.

8 Other platelet suspensions were frozen and thawed three times in siliconed tubes either in the presence of 200 mgm. of glass beads $0.1 \mathrm{~mm}$. in diameter, or without glass beads. Supernatants were separated as above.

utes the glass was removed and the plasma recalcified at $37^{\circ} \mathrm{C}$. There were no significant differences in the clotting time of plasma activated by glass at the different temperatures.

Method of decalcification of blood. Calcium was removed from blood with various decalcifying agents as indicated in Table II. In PF plasma obtained from blood treated with the calcium precipitating agents, sodium oxalate, sodium fluoride or with the chelating agents, EDTA or sodium citrate, clot-promoting activity developed on contact with glass. The decalcifying ion exchange resins Amberlite IRC 50 or Dowex 50 in contact with blood, themselves shortened the clotting time of the derived PF plasma. Contact of such plasma with glass did not result in further significant reduction of clotting time.

\section{Failure of glass to activate platelet clotting factors}

Varying quantities of platelets were treated with glass or were frozen and thawed in the presence of glass. After removal of the glass they were added to oxalated PF plasma and the recalcification time and residual serum prothrombin measured. The data in Table III show that the contact with glass did not affect the activity of platelet clotting factors.
3. Effect of contact of native or oxalated $P F$ $\mathrm{BaSO}_{4}-$ plasma with glass on clotting time, serum prothrombin and serum convertin content

Experiments in which glass acted upon three kinds of PF plasma: native, oxalated and oxalated $\mathrm{BaSO}_{4}$-treated (prothrombin-, PTC-, and proconvertin-free) are recorded in Table IV. In the case of native plasma the glass powder remained during clotting. With the oxalated plasmas, the clotting activity developed by contact with glass was tested, after removal of the glass, on oxalated PF plasma not treated with glass.

The clot-promoting activity developed by glass in $\mathrm{PF}$ native plasma and oxalated plasma was demonstrated by shortening of clotting time and appearance of serum convertin. On the other hand, the action of glass on the oxalated $\mathrm{BaSO}_{4}$ plasma resulted in the development of clot-promoting activity with no appearance of convertin in the clotting mixture.

The serum prothrombin measured by the method of Owren and Aas (17) which gives prothrombin values independent of the variation in serum convertin content, was slightly decreased in all three kinds of glass activated plasma. Serum prothrombin values obtained by the method of Rosenfield and Tuft (16) express the combined activity of residual serum prothrombin and con- 
TABLB IV

Effect of contact of native or of axalated BaSO,-treated PF plasma with glass on clotting time, serum prothrombin and convertin content

\begin{tabular}{|c|c|c|c|c|c|c|c|}
\hline & \multirow{4}{*}{$\begin{array}{c}\begin{array}{c}\text { Experi- } \\
\text { ment } \\
\text { No.* }\end{array} \\
1 \\
2 \\
3 \\
4 \\
5 \\
6 \\
7 \\
8\end{array}$} & & & \multicolumn{2}{|c|}{$\begin{array}{l}\text { Oxalated PF plasmaf } \\
0.2 \mathrm{ml} \text {. }\end{array}$} & \multicolumn{2}{|c|}{$\begin{array}{c}\text { Oxal. PF } \\
\mathbf{0 . 2} \text { ml. }\end{array}$} \\
\hline & & \multicolumn{2}{|c|}{$\begin{array}{l}\text { Native PF plasmat } \\
0.5 \mathrm{ml} \text {. }\end{array}$} & $\begin{array}{c}\text { Without } \\
\text { glass }\end{array}$ & $\begin{array}{c}\text { Glass } \\
\text { treated }\end{array}$ & $\begin{array}{c}\text { Witho } \\
\text { glass }\end{array}$ & $\begin{array}{l}\text { Glass } \\
\text { treated }\end{array}$ \\
\hline & & \multirow{2}{*}{$\begin{array}{c}\begin{array}{c}\text { Without } \\
\text { glass }\end{array} \\
23 \\
25 \\
18 \\
19 \\
15\end{array}$} & \multirow{2}{*}{$\begin{array}{c}\begin{array}{c}\text { Glass } \\
\text { treated }\end{array} \\
7 \\
4 \\
3 \\
7 \\
5\end{array}$} & \multicolumn{2}{|c|}{$\begin{array}{c}\text { Oxalated } \\
0.2 \mathrm{ml} .\end{array}$} & \multicolumn{2}{|c|}{$\begin{array}{c}\text { Oxalated } \stackrel{+}{\mathbf{P F}} \text { plasma } \\
\mathbf{0 . 2} \text { ml. }\end{array}$} \\
\hline $\begin{array}{l}\text { Clotting time } \\
(\text { min. })\end{array}$ & & & & $\begin{array}{l}12 \\
14 \\
15 \\
17 \\
14 \\
20 \\
20 \\
14\end{array}$ & $\begin{array}{r}4 \\
7 \\
6 \\
7 \\
10 \\
8 \\
6 \\
5\end{array}$ & $\begin{array}{l}45 \\
23 \\
17 \\
19 \\
24 \\
16 \\
29 \\
30\end{array}$ & $\begin{array}{r}13 \\
10 \\
8 \\
11 \\
15 \\
10 \\
19 \\
11\end{array}$ \\
\hline $\begin{array}{c}\text { Serum } \\
\text { pro- } \\
\text { thrombin\& } \\
(\%)\end{array}$ & $\begin{array}{l}1 \\
2 \\
3 \\
4 \\
5 \\
6 \\
7 \\
8\end{array}$ & $\begin{array}{r}120 \\
130 \\
110 \\
160 \\
90\end{array}$ & $\begin{array}{l}118 \\
300 \\
160 \\
400 \\
115\end{array}$ & $\begin{array}{r}82 \\
110 \\
48 \\
40 \\
100 \\
70 \\
100 \\
70\end{array}$ & $\begin{array}{r}93 \\
60 \\
20 \\
15 \\
85 \\
76 \\
150 \\
82\end{array}$ & $\begin{array}{l}20 \\
16 \\
20 \\
13 \\
52 \\
21 \\
32 \\
24\end{array}$ & $\begin{array}{l}15 \\
19 \\
17 \\
15 \\
60 \\
16 \\
22 \\
16\end{array}$ \\
\hline $\begin{array}{c}\text { Serum } \\
\text { pro- } \\
\text { thrombin\| } \\
(\%)\end{array}$ & $\begin{array}{l}1 \\
2 \\
3 \\
4 \\
5 \\
6 \\
7 \\
8 \\
8\end{array}$ & $\begin{array}{r}90 \\
100 \\
100 \\
85 \\
100\end{array}$ & $\begin{array}{r}60 \\
90 \\
75 \\
55 \\
100\end{array}$ & $\begin{array}{r}78 \\
58 \\
44 \\
48 \\
78 \\
73 \\
100 \\
60\end{array}$ & $\begin{array}{l}36 \\
38 \\
10 \\
17 \\
40 \\
43 \\
75 \\
38\end{array}$ & $\begin{array}{l}25 \\
23 \\
24 \\
16 \\
44 \\
26 \\
36 \\
27\end{array}$ & $\begin{array}{l}14 \\
15 \\
12 \\
10 \\
40 \\
19 \\
32 \\
22\end{array}$ \\
\hline $\begin{array}{l}\text { Serum } \\
\text { convertin } \\
(\%)\end{array}$ & $\begin{array}{l}1 \\
2 \\
3 \\
4 \\
5 \\
6 \\
7 \\
8\end{array}$ & $\begin{array}{l}0 \\
0 \\
0 \\
0 \\
0\end{array}$ & $\begin{array}{r}60 \\
80 \\
32 \\
80 \\
5\end{array}$ & $\begin{array}{r}0 \\
0 \\
30 \\
25 \\
11 \\
21 \\
0 \\
27\end{array}$ & $\begin{array}{r}15 \\
25 \\
100 \\
133 \\
21 \\
54 \\
57 \\
120\end{array}$ & $\begin{array}{r}0 \\
8 \\
0 \\
0 \\
10 \\
20 \\
15 \\
30\end{array}$ & $\begin{array}{r}3 \\
8 \\
0 \\
0 \\
12 \\
10 \\
0 \\
36\end{array}$ \\
\hline
\end{tabular}

* The clotting time, serum prothrombin and convertin values of the various plasmas derived from the same blood sample, are indicated by the same experiment number.

$\uparrow$ Clotting of $0.5 \mathrm{ml}$. of native $P F$ plasma without or with $50 \mathrm{mgm}$. of glass powder; the powder remained in contact with the plasma during clotting.

¥ Two-tenths ml. of glass activated oxalated PF- or oxalated PF BaSO,-plasma from which the glass was removed, was added to $0.2 \mathrm{ml}$. of oxalated $\mathrm{PF}$ plasma and recalcified with $0.1 \mathrm{ml}$. of $0.05 \mathrm{M} \mathrm{CaCl}$. For the controls, $0.2 \mathrm{ml}$. of non-activated plasma was used.

\$ Method of Rosenfield and Tuft (16).

If Method of Owren and Aas (17).

vertin; this may explain the variable results obtained and the apparent increase in "serum prothrombin" in the experiments with native plasma.

4. Development during contact with glass of a clot-accelerating activity in oxalated $P F$ hemophilia $A$ plasma rendered free of prothrombin, PTC, proconvertin, proaccelerin and fibrinogen

The data in Table $\mathrm{V}$ show that glass treatment of oxalated PF hemophilia A plasma induces clotpromoting activity, which shortens the clotting time of a mixture of such plasma with oxalated PF normal plasma. For the development of the clot-promoting activity in hemophilic plasma, fibrinogen, proaccelerin, proconvertin, PTC and prothrombin are not required. This activity is not well demonstrated unless antihemophilic factor $\mathrm{A}$ is present in the clotting mixture. This follows from the failure of glass to shorten the clotting time significantly in most of the hemophilic PF plasma samples (native as well as oxalated) to which normal plasma had not been added. 
TARLE $\mathbf{V}$

Chot-accelerating activity developed by contact with glass in oxalated $P F$ hemophilia $A$ plasma rendered free of prothrombin, PTC, proconvertin, proaccelerin and fibrinogen

\begin{tabular}{|c|c|c|c|c|c|c|c|c|c|c|c|c|}
\hline & \multicolumn{12}{|c|}{ Clotting time (min.) } \\
\hline & \multirow{3}{*}{\multicolumn{2}{|c|}{$\begin{array}{c}\text { Native PF } \\
\text { hemophilic } \\
\text { plasma* } \\
0.5 \mathrm{ml}^{*}\end{array}$}} & \multicolumn{10}{|c|}{ Oxalated PF plasma } \\
\hline & & & & & \multicolumn{2}{|c|}{$\begin{array}{l}\text { Hemophilict } \\
0.2 \mathrm{ml} \text {. }\end{array}$} & \multicolumn{2}{|c|}{$\begin{array}{c}\text { BaSO- } \\
\text { hemophilict } \\
0.2 \text { ml. }\end{array}$} & \multicolumn{2}{|c|}{$\begin{array}{l}\text { Stored BaSO } \\
\text { hemophilic } \\
0.2 \mathrm{ml}\end{array}$} & \multicolumn{2}{|c|}{$\begin{array}{l}\text { Heated BaSO } \\
\text { hemophilic } \\
0.2 \mathrm{ml} \text {. }\end{array}$} \\
\hline & & & \multicolumn{2}{|c|}{$\begin{array}{l}\text { Hemophilict } \\
0.4 \text { ml. }\end{array}$} & \multirow{2}{*}{$\begin{array}{r}\text { Without } \\
\text { glass } \\
\text { Norm } \\
0.2 \mathrm{~m}\end{array}$} & \multirow{2}{*}{$\begin{array}{l}\text { Glass } \\
\text { reated } \\
\text { ial } \\
\text { il. }\end{array}$} & \multirow{2}{*}{$\begin{array}{c}\text { Without } \\
\text { glass } \\
\text { Norm } \\
0.2 \mathrm{~m}\end{array}$} & \multirow{2}{*}{$\begin{array}{l}\text { Glass } \\
\text { treated } \\
\text { cal } \\
\text { nl. }\end{array}$} & \multirow{2}{*}{$\begin{array}{c}\text { Without } \\
\text { glass } \\
\text { Norm } \\
0.2 \mathrm{n}\end{array}$} & \multirow{2}{*}{$\begin{array}{l}\text { Glass } \\
\text { treated } \\
\text { hal } \\
\text { nl. }\end{array}$} & \multirow{2}{*}{$\begin{array}{c}\text { Without } \\
\text { glass } \\
\text { Norm } \\
0.2 \mathrm{~m}\end{array}$} & \multirow{2}{*}{$\begin{array}{l}\text { Glass } \\
\text { treated } \\
\text { al } \\
\text { al. }\end{array}$} \\
\hline & $\begin{array}{c}\text { Without } \\
\text { glass }\end{array}$ & $\underset{\text { treated }}{\text { Glass }}$ & $\begin{array}{c}\text { Without } \\
\text { glass }\end{array}$ & $\begin{array}{c}\text { Glass } \\
\text { treated }\end{array}$ & & & & & & & & \\
\hline $\begin{array}{l}\text { Z. Z. } \\
\text { F. M. } \\
\text { N. L. } \\
\text { E. S. } \\
\text { Y. M. }\end{array}$ & $\begin{array}{l}>180 \\
>180\end{array}$ & $\begin{array}{l}>180 \\
>180\end{array}$ & $\begin{array}{r}>180 \\
>180 \\
60 \\
>180 \\
68\end{array}$ & $\begin{array}{r}>180 \\
>180 \\
29 \\
80 \\
30\end{array}$ & $\begin{array}{l}26 \\
50 \\
60 \\
20 \\
45\end{array}$ & $\begin{array}{l}12 \\
16 \\
17 \\
12 \\
19\end{array}$ & $\begin{array}{r}30 \\
84 \\
68 \\
45 \\
120\end{array}$ & $\begin{array}{l}17 \\
18 \\
22 \\
18 \\
64\end{array}$ & $\begin{array}{r}35 \\
65 \\
49 \\
18 \\
180\end{array}$ & $\begin{array}{l}18 \\
30 \\
28 \\
12 \\
72\end{array}$ & $\begin{array}{l}18 \\
28 \\
\\
34 \\
54\end{array}$ & $\begin{array}{l}10 \\
14 \\
22 \\
32\end{array}$ \\
\hline $\begin{array}{r}\text { R.F. } \\
1951 \\
1954 \\
Y S T\end{array}$ & $\begin{array}{l}>180 \\
>180\end{array}$ & $\begin{array}{r}>180 \\
120\end{array}$ & $\begin{array}{l}>180 \\
>180\end{array}$ & $\begin{array}{r}>180 \\
48\end{array}$ & $\begin{array}{r}>180 \\
180\end{array}$ & $\begin{array}{r}>180 \\
38\end{array}$ & $\begin{array}{l}>180 \\
>180\end{array}$ & $\begin{array}{r}>180 \\
88\end{array}$ & $>180$ & $>180$ & & \\
\hline $\begin{array}{l}1951 \\
1954\end{array}$ & $\begin{array}{l}>180 \\
>180\end{array}$ & $\begin{array}{l}>180 \\
>180\end{array}$ & $\begin{array}{l}>180 \\
>180\end{array}$ & $\begin{array}{l}>180 \\
>180\end{array}$ & $\begin{array}{r}>180 \\
180\end{array}$ & $\begin{array}{r}>180 \\
24\end{array}$ & $\begin{array}{l}>180 \\
>180\end{array}$ & $\begin{array}{r}>180 \\
40\end{array}$ & $\begin{array}{r}>180 \\
100\end{array}$ & $\begin{array}{r}>180 \\
18\end{array}$ & $\begin{array}{r}>180 \\
45\end{array}$ & $\begin{array}{r}>180 \\
16\end{array}$ \\
\hline
\end{tabular}

- Clotting of $0.5 \mathrm{ml}$. of native PF hemophilic plasma with or without $50 \mathrm{mgm}$. glass powder; the glass powder remained in the plasma during clotting.

† Clotting of $0.4 \mathrm{ml}$. of oxalated $\mathrm{PF}$ hemophilic plasma, recalcified with $0.1 \mathrm{ml}$. of $0.05 \mathrm{M} \mathrm{CaCl}_{2}$. The glass powder was removed from the activated sample before recalcification.

$¥$ Two-tenths ml. of the various glass-activated oxalated PF hemophilic plasmas were added after removal of the glass to $0.2 \mathrm{ml}$. of oxalated $\mathrm{PF}$ normal plasma and the mixtures recalcified with $0.1 \mathrm{ml}$. of $0.05 \mathrm{M} \mathrm{CaCl}_{2}$. For the controls, $0.2 \mathrm{ml}$. of non-activated samples were used.

Oxalated $\mathrm{PF}$ hemophilic plasma was stored in a siliconed tube at $4^{\circ} \mathrm{C}$ for 18 days. (One stage prothrombin time more than 50 seconds.) The plasma was then treated with $\mathrm{BaSO}_{4}$.

\| PF BaSO,-hemophilic plasma was heated for $10 \mathrm{~min}$. at $56^{\circ} \mathrm{C}$. and the supernatant separated by centrifugation. The supernatant was fibrinogen-free as tested with thrombin and proaccelerin free as tested with the procedure of Stefanini (19).

I Both patients R. F. and Y.S. were examined twice. In 1951 both were "refractory" hemophiliacs and in 1954 both had again become responsive to normal plasma, evidenced by correction of clotting time and prothrombin consumption.

Noteworthy is the difference in the results obtained with the plasma of patients R. F. and Y. S. in 1951 and 1954. In 1951 both patients were "refractory hemophiliacs"; the prolonged clotting time and the disturbed prothrombin utilization of their blood could not be corrected by the addition of normal plasma. At that time glass treatment did not induce clot-promoting activity in their plasmas (21). In 1954 the blood of these patients had become responsive to normal plasma and paralleling this, glass treatment resulted in the appearance of the clot-promoting activity.

\section{Attempts to show adsorption of a clotting in- hibitor from plasma on glass powder}

Attempts were made to elute a clotting inhibitor, possibly adsorbed on glass which had been in contact with normal or hemophilic plasma. The glass powder, after contact with a considerable amount of plasma, was extracted with small quan- tities of 0.9 per cent $\mathrm{NaCl}$ or $0.1 \mathrm{M} \mathrm{CaCl}_{2}$ of different $\mathrm{pH}$ (range 4 to 12 ) or with ether, alcoholether 3:1, acetone or chloroform. The $\mathrm{NaCl}$ and $\mathrm{CaCl}_{2}$ eluates were tested directly on oxalated PF normal plasma, while organic solvent extracts were evaporated and the residues resuspended in 0.9 per cent $\mathrm{NaCl}$ before the test. In additional experiments the eluates were incubated with diluted brain thromboplastin extract for 10 minutes at $37^{\circ} \mathrm{C}$ and the clotting potency of the mixture was determined by the one stage prothrombin test system. In no case, however, could a clot retarding activity be detected in these eluates.

In another experiment (Table VI) one glass powder sample was brought into contact with successive aliquots of oxalated PF normal or hemophilic plasma and the clotting time (after removal of glass) and the protein and lipid adsorbed by the glass were determined. Although the glass powder during the successive contacts with new 
TABLE VI

Effect of contact of glass powder with successive aliquots of oxalated PF normal or hemophilic plasma on the clotting time and on the amount of protein and lipid adsorbed

\begin{tabular}{|c|c|c|c|c|c|c|}
\hline \multirow{3}{*}{$\begin{array}{l}\text { Contacts* of } \\
\text { glass powder } \\
\text { with plasma } \\
\text { aliquots }\end{array}$} & \multirow{2}{*}{\multicolumn{2}{|c|}{$\begin{array}{c}\text { Clotting time* of } \\
\text { plasma after contact } \\
\text { with the glass } \\
\text { powder sample }\end{array}$}} & \multirow{2}{*}{\multicolumn{2}{|c|}{$\begin{array}{l}\begin{array}{c}\text { Proteint on the } \\
\text { glass powder sample } \\
\text { after contact } \\
\text { with plasma }\end{array} \\
\text { (mgm.) }\end{array}$}} & \multirow{2}{*}{\multicolumn{2}{|c|}{$\begin{array}{l}\text { Esterified lipids } \ddagger \text { on } \\
\text { the glass powder } \\
\text { sample after con- } \\
\text { tact with plasma } \\
\text { (mgm.) }\end{array}$}} \\
\hline & & & & & & \\
\hline & Normal & $\begin{array}{l}\text { Hemo- } \\
\text { philic }\end{array}$ & Normal & $\begin{array}{l}\text { Hemo- } \\
\text { philic }\end{array}$ & Normal & $\begin{array}{c}\text { Hemo- } \\
\text { philic }\end{array}$ \\
\hline $\begin{array}{l}\text { No contact } \\
\text { First contact } \\
\text { Second contact } \\
\text { Third contact } \\
\text { Fourth contact } \\
\text { Fifth contact }\end{array}$ & $\begin{array}{r}15 \\
6 \\
5 \\
5 \\
6 \\
5\end{array}$ & $\begin{array}{l}80 \\
19 \\
16 \\
21 \\
24 \\
25\end{array}$ & $\begin{array}{l}0.28 \\
0.30 \\
0.27 \\
0.32 \\
0.33\end{array}$ & $\begin{array}{l}0.30 \\
0.35 \\
0.32 \\
0.30 \\
0.37\end{array}$ & $\begin{array}{l}0.17 \\
0.16 \\
0.14 \\
0.15 \\
0.16\end{array}$ & $\begin{array}{l}0.19 \\
0.17 \\
0.16 \\
0.18 \\
0.16\end{array}$ \\
\hline
\end{tabular}

* Two-ml. aliquots of oxalated PF plasma in 10 test tubes were activated each with 500 mgm. of glass powder. After centrifugation the supernatants were separated, pooled and a $0.4-\mathrm{ml}$. sample recalcified with $0.1 \mathrm{ml}$. of $0.05 \mathrm{M} \mathrm{CaCl}$. The glass powder from two tubes was processed as described below. To the glass powder in each of the remaining eight tubes a new $2-\mathrm{ml}$. aliquot of the original non-activated plasma was added and the above procedure was repeated each time with two tubes less.

+ After each contact experiment the glass powder from one tube was washed three times with $5 \mathrm{ml}$. of 0.9 per cent $\mathrm{NaCl}$ following which $1 \mathrm{ml}$. of $2.5 \mathrm{~N} \mathrm{NaOH}$ was added and the mixture heated on a boiling water bath for 20 minutes. The tyrosine-like activity of the supernatant was determined by the method of Herriott (22). As determined with this method the initial protein content of the normal plasma was $7.4 \mathrm{gm}$. per $100 \mathrm{ml}$., of the hemophilic plasma $7.9 \mathrm{gm}$. per $100 \mathrm{ml}$.

$\ddagger$ After each contact-experiment the glass powder from the second tube was washed as above and extracted with $3 \mathrm{ml}$. of alcohol-ether mixture 3:1. Esterified lipids were determined in the extract by the method of Stern and Shapiro (23). The plasma values obtained with this method were: normal $340 \mathrm{mgm}$. per $100 \mathrm{ml}$., hemophilic $370 \mathrm{mgm}$. per $100 \mathrm{ml}$.

plasma aliquots did not lose its ability to induce clot-promoting activity, the amount of protein and lipid adsorbed by the glass did not increase above that adsorbed during the first contact.

In the experiment recorded in Table VII, one sample of oxalated PF normal or hemophilic plasma was brought into contact with successive

TABLE VII

Effect of contact of a PF normal or hemophilic plasma sample with successive aliquots of glass powder on clotting time and plasma prothrombin content

\begin{tabular}{|c|c|c|c|c|}
\hline \multirow{2}{*}{$\begin{array}{l}\text { Contacts* of } \\
\text { plasma with } \\
\text { successive aliquots } \\
\text { of glass powder }\end{array}$} & \multicolumn{2}{|c|}{$\begin{array}{l}\text { Clotting timef } \\
\text { after contact with } \\
\text { glass powder } \\
\text { ( } \min .) \\
\end{array}$} & \multicolumn{2}{|c|}{$\begin{array}{l}\text { Plasma prothrom- } \\
\text { bint after contact } \\
\text { with glass powder } \\
\text { (\%) }\end{array}$} \\
\hline & Normal & $\begin{array}{c}\text { Hemo- } \\
\text { philic }\end{array}$ & Normal & $\begin{array}{l}\text { Hemo- } \\
\text { philic }\end{array}$ \\
\hline $\begin{array}{l}\text { No contact } \\
\text { First contact } \\
\text { Second contact } \\
\text { Third contact } \\
\text { Fourth contact } \\
\text { Fifth contact }\end{array}$ & $\begin{array}{r}18 \\
7 \\
7 \\
9 \\
11 \\
15\end{array}$ & $\begin{array}{l}80 \\
23 \\
19 \\
26 \\
35 \\
70\end{array}$ & $\begin{array}{r}100 \\
96 \\
94 \\
85 \\
75 \\
65\end{array}$ & $\begin{array}{r}100 \\
94 \\
94 \\
90 \\
82 \\
80\end{array}$ \\
\hline
\end{tabular}

* One plasma sample was activated five times with fresh aliquots of glass powder, $250 \mathrm{mgm}$. per $\mathrm{ml}$. The initial amount of plasma was $10 \mathrm{ml}$. After each contact with glass $2 \mathrm{ml}$. were removed for clotting and prothrombin tests.

$\dagger$ Four-tenths ml. of plasma were recalcified (after removal of glass) with $0.1 \mathrm{ml}$. of $0.05 \mathrm{M} \mathrm{CaCl}_{2}$.

$\ddagger$ Determined by the method of Owren and Aas (17). aliquots of glass powder. The shortening of the plasma clotting time after the first contact did not become more pronounced on repeated contacts with new glass; on the contrary, the clotting time again increased. The observed decrease in plasma prothrombin accompanying successive contacts of the plasma with glass, does not seem sufficient to explain the prolongation of the clotting time. However, evidence has also been obtained that the application of excessive amounts of glass to oxalated $\mathrm{PF}$ plasma results in diminution of plasma proconvertin activity (24). Whether the concentration of other clotting factors such as PTC, Factor X (25), etc. is also decreased by the successive contacts with glass, is not known.

These results indicate that the development of clot-promoting activity in plasma in contact with glass is not due to removal of a clotting inhibitor by adsorption onto the glass surface.

\section{DISCUSSION}

In the experiments described above it was observed that the clotting activity of isolated platelets, or of platelet clotting factors, liberated by freezing and thawing of isolated platelets, was not enhanced by contact with glass. On the other 
hand contact of "platelet free" (PF) plasma with glass induced a clot-promoting activity.

In the present study, the clot-accelerating activity induced by transient contact with glass in variously treated oxalated PF normal and hemophilic A plasmas was estimated. This was measured by the ability of such plasmas to shorten the recalcification time of mixtures of these plasmas with oxalated PF normal plasma. With this method it was possible to show that clot-promoting activity is developed by glass in PF hemophilia A plasma, rendered free of prothrombin, PTC, proconvertin, proaccelerin and fibrinogen. The clotting factor activated by glass in such plasma has not been identified. It is unlikely that the factor concerned is the "fourth thromboplastic factor" of Spaet, Aggeler, and Kinsell (26) or the Clotting Factor X (25), as these factors would have been destroyed by the heating to $56^{\circ} \mathrm{C}$ employed to remove fibrinogen from the test plasma. However, among other factors recently postulated to contribute to the evolution of blood thromboplastic activity, PTA (plasma thromboplastin antecedent, 27 ) and the "Hageman Factor" (28) might be present during activation by glass of the plasma system used here.

These observations do not disagree with the reported action of glass on proconvertin and PTC (9-11). Indeed some of them are compatible (Table IV) with the conclusions of Rapaport, Aas, and Owren (11) as to proconvertin activation by glass. Considerable serum convertin activity developed in native or oxalated PF normal plasma, on contact with glass. However when glass was applied to oxalated $\mathrm{BaSO}_{4}$-treated $\mathrm{PF}$ normal plasma (proconvertin free), no serum convertin developed when such plasma was added after removal of glass, to oxalated PF plasma (proconvertin containing), and the mixture recalcified. In this experiment, the action of glass resulted in shortening of clotting time of the mixture without development of detectable serum convertin. Glass thus seems to act on proconvertin as well as on other, yet unidentified factor(s).

Whether the greater clot-accelerating effect of glass present during clotting of oxalated PF plasma, as compared with the effect of glass when removed before recalcification (Table $I$ ), is due to an action on proconvertin or on other plasma factors, has not been elucidated. It is pertinent that the clotting of purified fibrinogen-thrombin mixture is accelerated in the presence of suspended glass powder, while removal of the glass powder after contact with the fibrinogen before the addition of thrombin does not result in shortened clotting time (24). It is possible that the finely divided glass particles present during clotting may promote the formation of primary fibrin strands.

The observations that the residual high level of serum prothrombin remaining after clotting of $\mathrm{PF}$ plasma was decreased when the plasma was treated with glass before recalcification are in agreement with those of Dick, Jackson, and Conley (8). However, as in the present experiments (Table VII) it was shown that after contact with a large area of glass prothrombin may be partly removed from plasma, we hesitate to attribute the decrease in serum prothrombin after contact with glass, to enhanced prothrombin utilization.

\section{SUMMARY}

1. The effect of glass on the evolution of clotpromoting activity in "platelet free" plasma was examined. Data are presented on the influence of the amount of glass, of the duration of contact, of the temperature and of the method of decalcification of the plasma on this process.

2. Contact of glass with isolated platelets or with platelet factors liberated by freezing and thawing, did not result in increase of their clotting activity.

3. Contact with glass induced a clot-promoting activity in oxalated hemophilia A plasma, free of platelets, prothrombin, PTC, proconvertin, proaccelerin and fibrinogen.

4. Attempts to demonstrate the adsorption of a plasma clotting inhibitor onto glass were unsuccessful. Contact with large area of glass was shown to remove some prothrombin from oxalated plasma.

\section{REFERENCES}

1. Lister, J., On the coagulation of blood. Proc. Roy. Soc., 1862-1863, 12, 580; other authors cited by Dick et al. (8).

2. Morawitz, P., Die Chemie der Blutgerinnung. Ergebn. d. Physiol., 1905, 4, 307.

3. Quick, A. J., The interrelationship of prothrombin, prothrombinogen, and labile factor. Conference on 
Blood Clotting and Allied Problems, 1950, vol. 3, p. 182.

4. Quick, A. J., and Epstein, E., Thromboplastic activity in human blood. J. Applied Physiol., 1952, 4, 840.

5. Conley, C. L., Hartmann, R. C., and Morse, W. I., II, The clotting behavior of human "platelet free" plasma: Evidence for the existence of a "plasma thromboplastin." J. Clin. Invest., 1949, 28, 340.

6. Ratnoff, O. D., and Conley, C. L., The rôle of surface and of calcium in the coagulation of a globulin fraction of platelet-deficient plasma. Bull. Johns Hopkins Hosp., 1951, 89, 245.

7. Hartmann, R. C., and Conley, C. L., Studies on the initiation of blood coagulation. III. The clotting properties of canine platelet-free plasma. J. Clin. Invest., 1952, 31, 685.

8. Dick, F. W., Jackson, D. P., and Conley, C. L., Surface as a quantitative factor in prothrombin utilization. J. Clin. Invest., 1954, 33, 1423.

9. Biggs, R., Douglas, A. S., and Macfarlane, R. G., The initial stages of blood coagulation. J. Physiol., 1953, 122, 538.

10. Alexander, B., de Vries, A., and Goldstein, R., A factor in serum which accelerates the conversion of prothrombin to thrombin. II. Its evolution with special reference to the influence of conditions which affect blood coagulation. Blood, 1949, 4, 739.

11. Rapaport, S. I., Aas, K., and Owren, P. A., The effect of glass upon the activity of the various plasma clotting factors. J. Clin. Invest., 1955, 34, 9.

12. Tocantins, L. M., Relation of contacting surface and anticephalin activity to the maintenance of the fluidity and coagulability of blood. Blood, 1946, $1,156$.

13. Fiala, S., On the role of a protein inhibitor in the first stage of blood coagulation. Arch. internat. de physiol., 1951, 58, 386.

14. Rees, H. M., and Ecker, E. E., An improved method for counting blood platelets. J.A.M.A., 1923, 80, 621.

15. Nevo, A., de Vries, A., and Katchalsky, A., Interaction of basic polyamino acids with the red blood cell. I. Combination of polylysine with single cells. Bioch. Biophys. Acta, 1955, 17, 536.

16. Rosenfield, R. E., and Tuft, H. S., Estimation of prothrombin level from prothrombin time. Am. J. Clin. Path., 1947, 17, 405.
17. Owren, P. A., and Aas, K., The control of dicumarol therapy and the quantitative determination of prothrombin and proconvertin. Scandinav. J. Clin. \& Lab. Invest., 1951, 3, 201.

18. de Vries, A., Alexander, B., and Goldstein, R., A factor in serum which accelerates the conversion of prothrombin to thrombin. I. Its determination and some physiologic and biochemical properties. Blood, 1949, 4, 247.

19. Stefanini, M., New one-stage procedures for the quantitative determination of prothrombin and labile factor. Am. J. Clin. Path., 1950, 20, 233.

20. de Vries, A., Herz, N., and Heiman-Hollander, E., Observations on prothrombin consumption during clotting of normal blood in glass. Acta med. Scandinav., 1950, 138, 219.

21. de Vries, A., and Shafrir, E., Méthode d'évaluation de lactivité thromboplastique du plasma. Applications cliniques et physiologiques. Rev. d'hemat., 1952, 7, 481.

22. Herriott, R. M., Reaction of Folin's reagent with proteins and biuret compounds in presence of cupric ion. Proc. Soc. Exper. Biol. \& Med., 1941, 46, 642.

23. Stern, I., and Shapiro, B., A rapid and simple method for the determination of esterified fatty acids and for total fatty acids in blood. J. Clin. Path., 1953, $6,158$.

24. Unpublished observations.

25. Duckert, F., Flückiger, P., Matter, M., and Koller, F., Clotting Factor X. Physiologic and physico-chemical properties. Proc. Soc. Exper. Biol. \& Med., 1955, 90, 17.

26. Spaet, T. H., Aggeler, P. M., and Kinsell, B. G., A possible fourth plasma thromboplastin component. J. Clin. Invest., 1954, 33, 1095.

27. Rosenthal, R. L., Properties of plasma thromboplastin antecedent (PTA) in relation to blood coagulation. J. Lab. \& Clin. Med., 1955, 45, 123.

28. Ratnoff, O. D., and Colopy, J. E., A familial hemorrhagic trait associated with a deficiency of a clotpromoting fraction of plasma. J. Clin. Invest., 1955, 34, 602.

29. Lanchantin, G. F., and Ware, A. G., Identification of a thromboplastin inhibitor in serum and in plasma. J. Clin. Invest., 1953, 32, 381.

30. Jürgens, J., Factor VII-inhibitor. A new physiological serum accelerator inactivation principle. Acta Haemat., 1955, 14, 57. 